\title{
CATERING SERVICES IN POLAND AND IN SELECTED COUNTRIES
}

\section{EWA RUTKOWSKA, ${ }^{1}$ EWA CZARNIECKA-SKUBINA ${ }^{2}$}

\section{RECEIVED}

ACCEPTED

JEL

CLASSIFICATION

KEYWORDS

ABSTRACT
Warsaw University of Life Sciences

${ }^{1}$ e-mail: ewa_rutkowska@onet.pl

2e-mail: ewa_czarniecka_skubina@sggw.pl

15 April 2015

1 June 2015

L81

catering, types of catering, catering companies

Present gastronomy in Poland and in the world is associated with the development of catering services, or off-site catering services: in the office, outdoors, at home, etc. Catering is a form of food services which fulfills consumer's nutritional needs and also organizes various events, their execution and ordering and delivery of food. There are several forms of catering. The development of services raises the level of offered service and the quality of the dishes prepared. The consumers gain trust to caterers through high quality services, such as: excellently prepared meals, food safety, fast timing service and the ability to prepare all kinds of events. Catering services in the world are characterized by high dynamics of development.

\section{Introduction}

In recent years, there has been a lot of positive changes in Polish gastronomy. These changes were influenced by global trends of globalization and assimilation of food service market to a large extent to the market of Western Europe. Industry catering services, especially catering services outside the plant are growing rapidly for many years. The reason for this is: 
- increased interest of individual and institutional clients in this form of services,

- addressing the declining numbers of canteens by caterers and reducing the costs of these services,

- enlarging consumer confidence and belief that caterers are using cheap and high quality products,

- bigger confidence in the safety of health food catering services offered by operators, due to the ownership, management related to food safety, and training of employees aiming to increase work efficiency and product quality,

- increasing the availability of this type of activity (Kelly, 1995; Wilson et al., 2001).

\section{Characteristic of catering services}

In different countries the concept is understood differently and stands out many variations. For example in Great Britain several types can be distinguished: traditional catering (including small businesses), contract catering (provision of services is based on a signed contract between the provider and the recipient), franchise catering (involves the use of a franchise system), popular catering (action for the purposes of wide audience), systemic catering (including action aimed at specific market), function catering (weddings, banquets, cocktail parties, business meetings).

In contrast, within the meaning of catering, in the US it can mean the following types of catering: banquet hall (where the customer comes to the service provider), off-premise (provides service to private homes, clubs, etc), mobile unit (called "mobile catering" and the basis for this service is a truck, which is specially designed for the distribution of meals).

\section{The social catering}

The market of social catering services includes contract catering and concession catering. The largest segments of the contract catering are hospitality, industrial companies canteens, social welfare centers. This part of the market has the greatest potential for use (Dolińska, 2001).

In contrast, the concession catering operates office buildings, as well as bars, buffets, and the serving events, banquets, conferences and picnics. Companies use these services for the preparation of business meetings. The organization of such events and banquets is the basis of up to $80 \%$ of the companies catering activity (Kobielska, 2009).

Social catering should also include the hospital catering. An assortment of prepared food in hospitals is wide, due to the variety of diets that have to be adapted to a number of diseases. The main problem in the portioning of food and meals expedition to patients is the selection of the nutrition and food distribution, which should provide high quality and maintenance of the required food temperatures at the lowest possible costs. The introduction of a centralized system of the tray was a big advance, because it enabled the preparation and portioning of dishes in the central kitchen, based on patient diets cards, which determine the type and size of the portions. The chance of getting a higher standard of food services in hospitality is the introduction of the cook - chill system (cook and refrigerate), which implements a change in the organization of hospital food block. Providing good work organization and hygiene conditions is particularly important because nutrition in hospitals is widely considered as a factor which supports the treatment (Czerwińska, 2001). 


\section{Office catering, which means "door to door service"}

It is a provision of prepackaged food for consumption in the workplace, such as salads, sandwiches, readymade food, confectionery, as well as hot dinners (Czarniecka-Skubina, 2000). As a part of the comprehensive service in the workplace, companies offer services to offices in the "room service" system and they supply the secretariats with food and drinks (Dolińska, 2001). Orders are usually carried out on the basis of the telephone notification, larger orders are usually contracted, which allows to negotiate prices of meals and provide free transportation. The dishes are packed in disposable tableware and transported in special packaging in order to maintain the proper temperature.

\section{Air Catering}

Satisfaction, and thus consumer confidence in the airline can be achieved by proper handling and suitable menu (An and Noh, 2009). Airline catering company serving for airlines and their passengers offers a wide range of dishes from the simple drinks during short flights for economy class to multi-coursed meals during long flights to the first and business class. Today, catering companies do not only provide food, but also keep a full service (Jones, 2004). As a service to aircraft catering trade offer may include: delivery of meals, commercial goods and equipment to aircraft, completing flight meals in wheelchairs, sale of commercial goods, dry ice and in cubes, additives and disposable equipment, newspapers and magazines, loading and handling of the aircraft in the field of catering services, waste disposal, laundry service, storage and warehousing of goods and equipment.

Flight catering organization stands up to specific conditions under which food must be served. Meals should be safe in terms of health and due to the limited space and lack of time for additional operations in the aircraft served as the easiest and fastest way. On board the meals have to be delivered on time. The air catering processes are completely related of airport operations. Characteristic of the process in air catering is that dish, tray or trolleys are assembled no earlier than 24 hours before the flight. The consumer may make changes to the configuration of the entire in-flight catering up to 30 minutes before departure (Gshirr, 2010). There are airlines that use the food supply on a contract basis. This situation requires enormous responsibility for air carriers to guarantee the microbiological quality of food supplied and thus forces them to implement the air food safety system based on the critical control points - HACCP. Plants of this type make use of food cooling technology (after the previous heat treatment), complete the food on trays, and then put the meal kits to air trucks.

\section{Railway catering}

Takes place in the dining cars specially adapted to the production and sale of food. There are also special trolley food carts selling beverages and packaged confectionery to train passengers (Ferenc et al., 2001).

\section{Commercial catering (also called party service, private catering)}

Catering companies offer their services to a variety of events, such as: breakfasts, lunches, buffets, dinners, weddings, galas, parties (birthday, anniversary, religious, holiday, corporate, office, university, school), dances, picnics, seminars, conferences meetings, conventions, charity, catering for concerts, private receptions and other. Some specialize only in particular services like exclusive parties, while others support all media events (press, 
cinema and television industry). In some cases a couple companies work together to support events such as weddings, etc.

Catering services generate large incomes, which is why companies are trying to show their best side by presenting differential and often highly sophisticated menu, very convenient location, etc. The menu of catering services is varied and includes various types of dishes: ethnic, kosher, vegan, for people with allergies and special dietary needs. In order to emphasize the special occasion it is often offering audiovisual equipment, light, music, fireworks and performances by artists and even rooms for babysitters (Czarniecka-Skubina, 2000).

\section{Catering in selected countries}

Canada - The institutional foodservice sector in Canada reached $\$ 3.8$ billion (C\$4 billion) in 2013. This sector consists of hospitals, residential care facilities, schools, prisons, factories, remote facilities and offices, including patient and inmate meals at correction facilities.

In 2013 in Canada food sales destined to retirement facilities and hospitals increased respectively $3.5 \%$ and $3.7 \%$, while for long-term care facilities increased by $11.4 \%$. Expected growth rate by commercial sub-sector in 2015-2018 years in Canada estimated depended on type of commercial establishments for: catering services on $4 \%$, Quick-service restaurants (QSR) - 4,1\%, full-service restaurants $-3,8 \%$ and drinking places $-1.4 \%$ (Arbulu, 2014).

China - Institutions such as hospitals, government, military, schools, airlines are supported by institutional catering. Most of these companies business is carried out on a small scale, while those institutions which have a high, international status still have a small share of the market.

According to the China Catering Association, the institutional food service sector would reach $\$ 216.7$ billion revenues by 2015 , or 30 to $40 \%$ of revenue of the entire Hotel Restaurants Industry. Institutional catering is not developed in China, because it is facing many difficulties, such as: small number of procedures for food safety, lack of procedures for completion of the work, management problems, control expenses, etc. Due to the increase of wealth, interest in private catering companies with food of a higher quality is increasing (Xian, 2015).

France - In France in the late 90s catering in various institutions (institutional food service) was carried out in $70 \%$ by their own nutritional services, and $30 \%$ by specialized companies. Most of the catering services in France (approximately 67\%) were performed by 4 largest companies (Table 1). Their services include covering the needs of business units, industrial, administrative, education and hospitals (Masłowski, 2002a).

Table 1. Characteristics of selected French companies providing catering services for institutions

\begin{tabular}{lcl}
\hline \multicolumn{1}{c}{ Company } & $\begin{array}{c}\text { Total market share } \\
(\%)\end{array}$ & \multicolumn{1}{c}{ The main business sectors in France } \\
\hline Sodexho & 22.0 & Administrative management $-47 \%$, Education $-24 \%$, Hospitals $-21 \%$ \\
Avenance & 21.5 & Economy and Administration, Education, Hospitals \\
Compass (Eurest) & 18.0 & Administration sector and the economy, Education, Hospitals \\
Sogeres & 5.0 & Economy and Administration $-48 \%$, Education $-34 \%$, Hospitals $-12 \%$, Events $-6 \%$ \\
\hline
\end{tabular}

Source: Gauthier (2009). 
Germany - Catering services in Germany stands for about $30 \%$ of the food services market. Catering is very popular among employers. Approximately $25 \%$ of employees use canteens (Masłowski, 2002a). Table 2 shows the characteristics of catering services in Germany.

Table 2. Characteristics of catering services in Germany in 1998

\begin{tabular}{llcl}
\hline \multicolumn{1}{c}{ The market segments } & Description of establishments & $\begin{array}{c}\text { The turnover value } \\
\text { (mln DM) }\end{array}$ & Notes \\
\hline $\begin{array}{l}\text { Nutrition in industry, commerce } \\
\text { and administration }\end{array}$ & $\begin{array}{l}\text { differentiated size - from medium } \\
\text { to large }\end{array}$ & 18,500 & $\begin{array}{l}2,097,853 \text { workshops, in this 108,000 employing more } \\
\text { than 20 people, and 3,357 - more than 500 person }\end{array}$ \\
\hline Nutrition in healthcare facilities & patients, personnel and guests & 29,000 & 13,551 hospitals, clinics and care facilities \\
\hline Nutrition in schools & $\begin{array}{l}\text { different - kindergartens, schools, } \\
\text { university canteens }\end{array}$ & \multirow{2}{*}{3,000} & $\begin{array}{l}43,118 \text { schools, 9,300 business schools, 337 } \\
\text { institution of higher education }\end{array}$ \\
\hline
\end{tabular}

Source: Masłowski (2002a); Rehder (2013).

Annual turnover in the German Institutional Sector (canteens and caterer) reached 22,5 billion $€$ in 2011 (Rehder, 2013). It was a 4,2\% compared to 2007 increase in this sector of catering services. The largest German catering companies are Compass, Aramark, Sodexo, Dussmann and Klüh (Table 3). About two-thirds of total sales in institutional foodservice sector came from company restaurants. The strongest growth in 2011 was registered in event's catering (Rehder, 2013).

Table 3. Developments in the individual sectors in Germany in 2011 year

\begin{tabular}{lccc}
\hline \multirow{1}{*}{ Catering } & \multicolumn{3}{c}{ Sales in sectors in €millions } \\
\cline { 2 - 4 } \multicolumn{1}{c}{ companies } & company Restaurants & hospitals & schools, universities \\
\hline Compass & 486.9 & 50.2 & - \\
Aramark & 309.0 & - & - \\
Sodexo & 124.9 & 140.7 & 78.5 \\
Dussmann & 89.0 & 60.0 & 25.0 \\
Apetito & 73.7 & - & 16.3 \\
Klüh & - & 108.0 & - \\
Schubert & - & 49.1 & - \\
Sander & & & 5.8 \\
SRH & & 641.6 & 5.6 \\
\hline Total & $1,452.0$ & & 151.1 \\
\hline
\end{tabular}

Source: Rehder (2013).

It is predicted that the foodservice sector in Germany will still develop, because of the increasing number of single households and an aging population.

Italy - In the last decades Italian people changed their lifestyles. More workers were forced to spend their lunch hours outside of the home due to either longer commuting times or shorter lunch breaks. It has heavily influenced the development of the food service industry. Italy is slowly moving towards trends and lifestyles seen in other European countries. It is forecasted that an increasing number of Italian consumers will be eating out during their lunch breaks and evening meals. This is due to long hours of work and business meetings. The Italian 
institutional sector is valued at about $€ 8$ billion and serves more than 5.5 million meals a day. The main Institutional Catering companies operating in Italy are Ristochef, Gama, Gemeaz, Onama, La Cascina and Sodexho (Biasetti, 2014).

Japan - The institutional food service sector in Japan had sales worth $\$ 33.6$ billion in 2013. This represented $11.1 \%$ of total food service industry sales. The institutional food service sector is comprised of four segments: business/office cafeterias (share 5,7\%), school lunch programs (share 1.7\%), hospitals (2.7\%), and child care facilities (Otsuka, 2015).

Netherlands - In Netherlands the greatest catering companies are Sodexo and Compass Group. Besides them there are many local catering companies: Albron Paresto, Vermaat Group, Jaarbeurs Catering Services, Koninklijke Van Den Boer Group, Hutten Catering, Prorest Catering, OSP Catering. Their turnover in $\$(1 \$=0.758 €)$ stated in the range of 53 up to 453 (Pinckaers, 2013).

Turkey - In Turkey the number of catering companies increased in the past decade, due to the development of the public and private sector, which are increasingly outsourcing the food services. The number of catering facilities increased from 300 in the 1970s to around 5,000 in 2014. The catering companies employ 400,000 people and provide meals to about 7 million people daily. It should be underlined that a half of them lives in Istanbul. Larger catering companies such as Sodexho, Compass, and Klüh are also in the Turkish market. The four largest companies (Sofra, Sardunya, Obasan and BTA) in the sector are listed among the top 1,000 industry companies announced by the Istanbul Chamber of Industry.

As Atalysun (2014) indicates, in Turkish culture, eating is a form of socialization that brings together family and friends. Lately, Turkish eating habits has changed, and Turks more often eat out. The causes were due to factors such as urbanization, increase in per capita income and the increase in the number of working women. In 2002, Turks ate out once a month, now people eat out at least 3 times a month (this average is at least once a week in Istanbul).

Institutional food service providers began emerging in Turkey in the late 1970s and early 1980s, and the institutional food service sector has developed since then. It was to provide food services to factories, schools, hospitals, private companies and public sector organizations. This trend spread from Istanbul to other large cities such as Ankara, Izmir, Adana, Bursa and Eskisehir.

The institutional food sector is growing by providing catering to the military and educational sector - schools. Sales in catering services in Turkey are now a $\$ 7$ billion market compared to $\$ 2.25$ billion in 2004 , accounting for over $30 \%$ of the overall HRI sector. The Turkish Federation of Catering Associations (YESIDEF) is conducting various projects, for example "Feeding the New Generation" to increase sales to the schools and military facilities. These projects hope to serve 17 million students and 555,000 teachers in 69,000 schools. At present 110,000 soldiers are served in 43 units in Turkey. It is planned that this number will increase up to 650,000 soldiers.

The sector is now aiming to improve quality standards. It has been shown that Turks spend annually as much as $\$ 30$ billion for the treatment of obesity, heart attacks, diabetes. To prevent this situation we could serve healthy meals in schools, where the amount could be intended to contain only $20 \%$ of the total expenditure of the population that bears the fight against diet-related diseases ( $\$ 30$ billion). The increase in demand for professional kitchens influenced the desire to create cooking schools by private institutions. The financial benefits of this sector reached the amount of $\$ 9,7$ million (Atalysun, 2014). 
United Kingdom - It is estimated that in the UK there are around 0.5 million catering companies (Griffith and Clayton, 2005). Their short characteristics is presented in Table 4. They provide commercial and social catering. In the 90 s an increase in outsourcing food services was observed in this sector, especially in the public sector along with a significant increase in turnover. For example Feeding program in the UK covered $70 \%$ of the pupils (feeding program included 70\% of the students) (Masłowski, 2002b; Vasquez-Nicholson, 2014).

Table 4. Catering companies in the UK

\begin{tabular}{|c|c|}
\hline Category & Characteristic \\
\hline Operators & $\begin{array}{l}\text { Operating a foodservice outlet includes all the functions associated with both 'front' and 'back' of house, including } \\
\text { kitchen operations and meal preparation. All of the operating functions can be undertaken by the owner. Foodservice } \\
\text { operators: Compass Group, Sodexho. }\end{array}$ \\
\hline Staff Catering & $\begin{array}{l}\text { These include trolley services, as well as areas where full meals are sold, e.g., self-run canteens, contracted canteens, } \\
\text { national government canteens, off-shore catering. Foodservice operators: Compass Group, } 3663 \text { First for Foodservice. }\end{array}$ \\
\hline Education & $\begin{array}{l}\text { This includes food and drinks served in schools of all levels from nurseries to universities. In recent years, meals served } \\
\text { by catering operators have been changed. There are more healthy and nutritious. The leading contract school caterers } \\
\text { are Compass's Scolarest Division, Initial Catering Services, and Sodexho, Aramark Ltd., } 3663 \text { First for Foodservice. }\end{array}$ \\
\hline Health Care & $\begin{array}{l}\text { Meals counted in the health care sector include those served to patients, staff and visitors and include: hospitals, } \\
\text { nursing homes and care homes. As with the educational sector, nutritional needs are under scrutiny in this area. } \\
\text { Foodservice operators: Aramark Ltd., Compass Group, } 3663 \text { First for Foodservice. }\end{array}$ \\
\hline Custodial & $\begin{array}{l}\text { This includes police stations, fire stations, the armed forces, and prisons. The vast majority of the catering for the } \\
\text { armed forces is managed by the Ministry of Defense but it hires the defense divisions of Sodexho, Compass Group } \\
\text { and Aramark. }\end{array}$ \\
\hline
\end{tabular}

Source: Vasquez-Nicholson (2014).

Due to the large number of companies operating within the food service market, intermediaries skilled in fulfilling small orders efficiently play a pivotal role in the distribution of products.

The following companies are some of the biggest caterers in the UK foodservice industry:

1. Aramark Ltd. is a leader in professional services providing award winning food services and facilities management. Number of sites: 1200.

2. The Compass Group is a leading foodservice company. They have over 400,000 employees and specialize in providing food, vending and related services to clients in over 90 countries. Number of sites: 7000 .

3. 3663 First for Foodservice is the UK's leading foodservice company with sales of over $£ 1$ billion a year. They deliver to over 50,000 customers: ingredients, finished products and equipment to the catering industry. They have a fleet of 1,100 vehicles.

4. Sodexho UK Ltd. has 48,000 employees in the UK and Ireland have more than 2,300 clients (Vasquez-Nicholson, 2014).

\section{Catering services in Poland}

The factors in the development of catering services in Poland include: GDP growth in the country, the increase in employment, an increase in private consumption, growth in average sales, an increase in the level of education and skills, an aging population, the impact of globalization, travelling, etc. (Levytska, 2008). For now, a few consumers are still deciding for a meal outside the home, for example in the company cafeteria. However 
constantly growing lack of time, late returns home, too many activities are the cause of the use of canteens and cafeterias (Kowrygo, 2009). The necessity of consuming meals at school and work in Poland is growing, so it is important to extend services in this area.

On the Polish market international companies are operating - catering operators who provide comprehensive caterer services under the contract with the companies. Among the biggest companies one can distinguish a Lot Catering, which has been operating since 1992 in the field of in-flight catering and organization of special events, conferences and business meetings and office catering. Eurest Poland is operating on the Polish market since 1993 and organizes banquets, staff canteens, lunchrooms. Since 2009, Eurest Poland launched Development Center of Excellence (Eurest Poland, 2015). Sodexho Poland also works since 1993. It mainly provides services like office catering and staff canteens (Sodexho Poland, 2015). The company Impel Catering is also developing rapidly since 1991. Its activities include the organization of special events, conferences and canteens.

In Poland we can find the package of offered services called Full Service Management (complete services) which includes technological design, construction supervision, technical consulting, preparation and serving of meals based on customer needs and a comprehensive nutritional support for its activities with supervision of staff, menu planning, organization, logistics, cleaning, catering area among them.

Railway catering is operated by the company WARS SA, existing in the passenger transport market for over 60 years. The basic areas of activity WARS SA include 69 dining cars ( 19 for restaurant and 50 for bars), 57 sleeping cars, 35 rest cars WARS catering supports travelers in dining cars and bars selling snacks and drinks from the mini bar for travelers in passenger compartments, catering on the train at the customer's request and a special service for tourist groups. The company has also opened a restaurant called 'Green Patio' where meals are prepared in terms of high nutritional value, as well as 'Piada' bar with quick Italian style snacks (WARS, 2012).

Specialized catering company has introduced a lot of novelties to Polish gastronomy such as cashless forms of payment, like magnetic cards and lunch vouchers. Design and offer staff canteens were also updated.

This eliminates uninteresting and monotonous menu and provides a new, attractive arrangement consumption rooms, varied menu (salad buffets, meals from national cuisine).

Less attention of catering operators is directed to investing in schools and hospital cafeterias. Hospitals are interested in the operation aimed to improve nutrition, but it is known that many hospital kitchens are in bad conditions and need modernization. Economic considerations have decided that the feeding part of the armed forces of Poland in 2002, was passed on to civil caterers. Caterers also handed operations in canteens, casinos, soldiers' clubs and laundry facilities. It is also important that caterers can modernize eating and food preparation in military bases (Czerwińska, 2001).

\section{Conclusions}

The phenomenon takes place in countries that stand out in terms of national income. Such a dynamic development of catering services is due to trust of customers to secure in terms of hygiene and health products and the increasing belief that caterers can distribute cheaper and better products. Their own "management" responsible for food safety and training employees in order to increase efficiency and product quality also contributes to the success of catering companies. 
Among the major catering companies operating in the world one can easily distinguish international companies, such as: Eurest, Sodexho, Compass Group and Granada Food Services, which in 2000, set up Granada Compass (Wilson et al., 2001).

The clients of catering services are represented by large companies, corporations, hotel chains and individual clients. The menu is diverse, adapted to the clients, but more often they offer health benefits. These companies deal with the employee canteens, business meetings, banquets, social catering (canteens, hospitals, schools) and office catering. To acquire customers are introduced all sorts of innovations such as healthy eating programs. Characteristic of today's catering business is respecting the principles of sustainable development in all aspects of the organization, supporting Fairtrade and philanthropy. For example, Sodexho is a partner of the event 'STOP Hunger'. This program provides hot meals to needy children in approximately 25 countries worldwide (Wilson et al., 2001).

In Poland catering is not as developed as in Western Europe or in the USA. This is due to the fact that the income of the population in Poland is much lower than in the well-developed countries. However, interest in catering services is increasing due to the lack of time, late home returns and too many responsibilities. Interest in catering is also a trend associated with the consumption of meals outside the home among friends and family.

\section{References}

An, M. \& Noh, Y. (2009). Airline customer satisfaction and loyalty: impact of in-flight service quality. Service Business, 3: $293-307$.

Arbulu, M. (2014). Canada Food Service - Hotel Restaurant Institutional. Overview of the HRI Sector in Canada. GAIN Report No. CA14118. USDA Foreign Agricultural Service. Food Service - Hotel Restaurant Institutional_Ottawa_Canada_12-20-2014. pdf. Available at: http://gain.fas.usda.gov (accessed on 4.04.2015).

Atalysun, M. (2014). Turkey Food Service - Hotel Restaurant Institutional Turkey HRI Annual Report. GAIN Report No. TR4059. USDA Foreign Agricultural Service, Available at: www.calwinexport.com/files/FoodServiceHotelRestaurantInstitutional_Ankara_ Turkey_12-31-2014.pdf (accessed on 4.04.2015).

Biasetti, D. (2014). Italy Food Service Hotel Restaurant-Institutional 2014. GAIN Report No. IT1496. USDA Foreign Agricultural Service, Food Service-Hotel Restaurant Institutional_Rome_Italy-12-5-2014.pdf.

Czarniecka-Skubina, E. (2000). Działalność firm cateringowych. Poradnik Restauratora, 3: 28-29.

Czerwińska, E. (2001). Kto przygotuje wojskową grochówkę. Poradnik Restauratora, 10: 18.

Dolińska, I. (2001). Catering po polsku. Food Service, 4: 14-15.

Eurest Poland (2015). Available at: www.eurest.pl (accessed on 5.04.2015).

Ferenc, W., Biller, E., et.al. (2001). Kucharz \& Gastronom. Warszawa: Rea.

Gauthier, R. (2009). France HRI Food Service Sector. Enter a Descriptive Report Name 2009. GAIN Report No. FR9013, USDA Foreign Agricultural Service, HRI FOOD SERVICE SECTOR_Paris_France_7-20-2009.pdf. Available at: http://gain.fas.usda. govl (accessed on 4.04.2015).

Griffith, Ch.J. \& Clayton, D. (2005). Food safety knowledge attitudes and practices of caterers in the UK. In: B. Maunsell \& D.J. Bolton, Restaurant and catering food safety: Putting HACCP on the menu. Ireland: Ashtown Food Research Centre Dublin Ireland, Ch. 5.

Gschirr, M. (2010). Planning and realization of innovative airline catering production: industrial case study. Production Engineering Research and Development, 4: 371-377.

Jones, P. (2004). Flight catering. 2nd ed. Oxford: Butterworth-Heinemann.

Kelly, P.W. (1995). The catering industry in the Republic of Ireland. International Journal Hospitality Management, 14: 25-37.

Kobielska, Z. (2009). Rynek cateringu rośnie. Gastronomia, 1: 25-27.

Kowrygo, B. (2000). Evaluation of the development of catering Services in Poland in the 90-ties. Annals of Warsaw Agricultural University. Food Technology. Nutrition and Consumer Sciences, 22: 13-21.

Levytska, G. (2008). Zachowania konsumentów na rynku usług gastronomicznych w centrach handlowych na przykładzie Warszawy. XIII Warsztaty Ekonomistów Rolnych: 1-30. 
Masłowski, A. (2002a). Catering w krajach gospodarki rynkowej. Poradnik Restauratora, 2: 14-17.

Masłowski, A. (2002b). Polska gastronomia w transformacji systemowej. Poradnik Restauratora, 1: 7.

Otsuka, M. (2015). Japan HRI Food Service Sector Report 2014. GAIN Report No. JA4519. USDA Foreign Agricultural Service. Food Service - Hotel Restaurant Institutional_Tokyo ATO_Japan_2-26-2015.pdf. Available at: http://gain.fas.usda.gov (accessed on 4.04.2015).

Pinckaers, M.H. (2013). Netherlands Food Service - Hotel Restaurant Institutional. An overview of the HRI Market in the Netherlands and Belgium. GAIN Report No. NL3023. USDA Foreign Agricultural Service. Food Service-Hotel Restaurant Institutional_The Hague_Netherlands_9-16-2013.pdf. Available at: http://gain.fas.usda.gov (accessed on 4.04.2015).

Rehder, L.E. (2013). Germany Strong Food Service Growth. Food Service - Hotel Restaurant Institutional 2013. GAIN Report No. GM13002. USDA Foreign Agricultural Service. Strongest Growth in Recent Years_Berlin_Germany_EU-27-1-4-2013.pdf. Available at: http://gain.fas.usda.gov (accessed on 4.04.2015).

Sodexho Poland (2015). Available at: www.sodexo.pl (accessed on 5.04.2015).

Xian, V. (2015). China-Peoples Republic of Food Service - Hotel Restaurant Institutional HRI Food Service Sector Annual Report. GAIN Report Number CH156006. USDA Foreign Agricultural Service. Food Service-Hotel Restaurant Instututional-GuangzhouATOChina-PeoplesRepublicof-2-10-2015.pdf. Available at: www.globalorganictrade.com (accessed on 5.04.2015).

Vasquez-Nicholson, J. (2014). United Kingdom Food Service - Hotel Restaurant Institutional 2014. USDA Foreign Agricultural Service, Food Service - Hotel Restaurant Institutional-London-United Kingdom-12-12-2014.pdf. Available at: www.calwinexport.com (accessed on 5.04.2015).

WARS (2012). Materiały reklamowe firmy.

Wilson, M.D.J., Murray, A.E. \& McKenna-Black, M.A. (2001). Contract catering: a positional paper. Hospitality Management. 20: 201-218.

Cite this anticle aS: Rutkowska, E., Czarniecka-Skubina, E. (2015). Catering services in Poland and in selected countries. Szczecin University Scientific Journal, No. 872. Service Management, 15 (1): 13-22. 